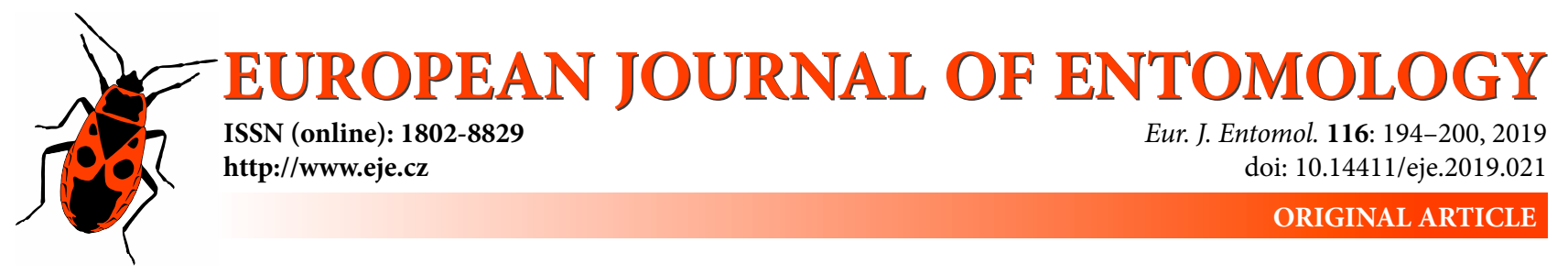

\title{
The role of iron (Fe) in the population dynamics of pistachio psyllid, Agonoscena pistaciae (Hemiptera: Aphalaridae) in Pistacia orchards
}

\author{
Hossein DEHGHANI-YAKHDANI ${ }^{1}$, Shahzad IRANIPOUR ${ }^{1, *}$, Mohammad Reza MEHRNEJAD ${ }^{2}$ \\ and REZA FARSHBAF-POURABAD ${ }^{1}$ \\ ${ }^{1}$ Department of Plant Protection, Faculty of Agriculture, University of Tabriz, Tabriz, Iran; e-mails: hosseindeh@yahoo.com, \\ shiranipour@tabrizu.ac.ir, rfpourabad@tabrizu.ac.ir \\ 2 Pistachio Research Institute, Rafsanjan, Iran; e-mail: Reza_mehrnejad@hotmail.com
}

Key words. Hemiptera, Aphalaridae, Agonoscena pistaciae, pistachio psyllid, Pistacia, host plant quality, life table, nutrient fertilizer, population density, intrinsic rate of increase, central Iran

\begin{abstract}
The common pistachio psyllid (CPP) is thought to respond to nutrient availability in pistachio trees. We determined the effect of a deficiency of leaf iron (Fe) has on the abundance of the pistachio psyllid at a regional scale. First, we monitored the abundance pistachio psyllid in four pistachio orchards (24 trees as 24 repetitions) located in Maybod County, Yazd province in the centre of Iran and then measured leaf nutrient levels. Orchards were located up to $2.6 \mathrm{~km}$ apart. Multivariate regressions were used to determine the relationship between leaf nutrients and CPP population growth. The results indicate that the number of psyllid eggs and population growth rate of the nymphs was negatively correlated with Fe levels in the leaves, while peak numbers of psyllid eggs were positively correlated with the levels of $\mathrm{Cu}$ in the leaves. In a manipulative field experiment, we conducted two experiments: (1) pistachio trees treated with iron compared with control trees, and (2) pistachio trees previously treated with iron were treated with ammonium sulphate and compared with trees treated with ammonium sulphate. In the first experiment, psyllids in leaf disc-cages had a significantly greater intrinsic rate of population increase and net reproductive rate on Fe-treated trees than the control trees (Stage 1). In the second experiment, psyllids in leaf disc-cages had similar intrinsic rates of population increase and net reproduction both on the ammonium sulphate treated trees (control) and those previously treated with iron. This indicates that iron may have reacted negatively with nitrogen content of the leaves. In general, these findings indicate that when there is a deficiency of iron in the leaves, the application of nitrogen fertilizer had little effect on the performance of CPP and may have played a minor role in the population dynamics of CPP, but the application of a Fe fertilizer without considering the nitrogen content of the leaves may lead to a population outbreak.
\end{abstract}

\section{INTRODUCTION}

Pistacia vera Linnaeus (Sapindales: Anacardiaceae) is the most important Iranian horticulture product. Numerous insects and herbivorous mites attack pistachio trees. One of the pistachio key pests is the common pistachio psyllid Agonoscena pistaciae Burckhardt \& Lauterer (Hemiptera: Aphalaridae), which annually damages most pistachio orchards in Iran (Mehrnejad, 2010). High population densities of psyllid nymphs and adults result in bud drop and defoliation as well as abnormal kernel development and significant economic losses (Mehrnejad, 1998, 2003).

In the centre of Iran, Yazd-Meybod County, the population density of common pistachio psyllid varies considerably from year to year, and even between adjacent farms. Currently, little is known about the factors affecting the abundance and outbreaks of the common pistachio psyllid. Previous studies indicate that top-down factors do not play an important role in the population fluctuations of CPP. Natural enemies of CPP are mainly ladybirds (Jalali, 2001; Arab-Hormozabadi, 2005; Hassani et al., 2009; Mehrnejad, 2010; Mehrnejad et al., 2015); however, many other predatory arthropods, including predatory mites (Phytoseiidae, Anystidae, and Erythraeidae; Mehrnejad \& Ueckermann, 2001, 2002), lace-wings (Chrysopidae; Kazemi \& Mehrnejad, 2011), predatory bugs (Anthocoridae and Miridae; Pourali et al., 2012) and parasitoid wasps (Encyrtidae; Mehrnejad, 1998; Ebrahimi et al., 1999; Mehrnejad \& Emami, 2005) attack CPP in Iran. Population fluctuations of CPP in different years and on different farms may depend mainly on bottom-up factors e.g. the host's nutritional quality. Mehrnejad (2003) report differences between pistachio varieties, which affect the population densities of this pest in the field. Access to soil nutrients may also play a role in the performance of CPP and

\footnotetext{
* Corresponding author; e-mail: shiranipour@tabrizu.ac.ir
} 
affect the likelihood of population outbreaks through its effect on host plant quality.

The quality and quantity of the minerals available to insect herbivores may significantly affect their growth and fecundity. In this regard, mineral nutrients may interact with other components in their diet and environmental factors (Awmack \& Leather, 2002).

Most studies on the effect of fertilizers on the abundance of pests are on aphids, since their response varies considerably. Compared to aphids, there are very few articles on other pests (Chau et al., 2005). In this regard, there are more studies on the effect of three macronutrients (nitrogen, potassium and phosphorus), because of their importance for plants and their high probability of affecting the abundance of herbivorous insects (Awmack \& Leather, 2002; Jansson \& Ekbom, 2002).

Application of a nitrogen fertilizer can increase the nitrate and soluble amino acid content of plants. Amino acids are important in the growth and reproduction of aphids and other sap sucking insects (Mengel \& Kirkby, 1982; Jansson \& Smilowitz, 1986; Golan et al., 2017).

Nitrogen and potassium can both increase the amount of soluble nitrogen in plants, which renders them more favourable for aphids (Auclair, 1965).

Potassium deficiency disrupts protein synthesis and thus increases the level of soluble amino acids and nitrogen and decreases the concentration of sugar in plants, which makes them more suitable for aphids (Mengel \& Kirkby, 1982; Dale, 1988; Myers \& Gratton, 2006). In comparison with aphids, there are few studies on the effect of fertilizers on the abundance of other insects.

The egg density and numbers of nymphs of Psylla pyricola Foerster increase faster in orchards treated with high amounts of nitrogen fertilizer. Probably, P. pyricola prefers leaves with a high nitrogen content and the amount nitrogen fertilizer rather than the time of application has a great effect on the numbers of pear psyllid (Pfeiffer \& Burts, 1983).

Iron is an important micronutrient for many organisms since it is an essential component of important metabolic processes such as DNA synthesis, respiration and photosynthesis. In plants, iron is important for chlorophyll synthesis, and essential for maintaining chloroplast structure and function.

In addition, iron plays a role in protein metabolism. When there is a deficiency of iron, the protein fraction is low and the level of soluble organic nitrogen compounds is high (Rout \& Sahoo, 2015).

The purpose of this study was to investigate the effect of fertilizers on CPP populations at a regional scale in order to determine the relationship between micro and macronutrients and CPP performance.

To understand the relationship between micro and macronutrient levels in pistachio leaves and the dynamics of CPP populations, we used two approaches. First, we determined the growth rate of CPP populations along a natural gradient in the level of micro and macronutrients in pistachio orchards throughout Yazd-Meybod County. Second, we experimentally manipulated the level of iron in the soil in order to elucidate the effect it has on CPP performance. The results of this study will increase our understanding of the variations in the level of mineral nutrients in soil and pistachio leaves, and their effect on the abundance of CPP and the extent to which host plant quality affects the abundance of CPP.

\section{MATERIALS AND METHODS}

\section{Regional studies}

In late winter of 2016, four orchards in Yazd-Meybod County were selected for recording the abundance of CPP and measure the levels of minerals in the leaves of the trees. The locations of the orchards extended over a distance of $2.6 \mathrm{~km}$. The coordinates of the sites were: $1-32^{\circ} 16^{\prime} 4^{\prime \prime} \mathrm{N}, 53^{\circ} 58^{\prime} 50^{\prime \prime} \mathrm{E}, 2-32^{\circ} 16^{\prime} 9^{\prime \prime} \mathrm{N}$, $53^{\circ} 58^{\prime} 54^{\prime \prime} \mathrm{E}, 3-32^{\circ} 16^{\prime} 54^{\prime \prime} \mathrm{N}, 53^{\circ} 59^{\prime} 8^{\prime \prime} \mathrm{E}$ and $4-32^{\circ} 17^{\prime} 23^{\prime \prime} \mathrm{N}$, $53^{\circ} 59^{\prime} 24^{\prime \prime} \mathrm{E}$. At each site, an orchard was selected, and in each of them, six trees were selected, three of which were fertile (ON year) and three were infertile (OFF year) (60-70-year old trees). Each tree was considered as a repetition (Randomized Complete Block Design). Other factors including cultivar, tree age, nutrition, environmental temperature, water's EC, irrigation, spraying and soil texture may also affect the abundance of this pest. For this reason, all the orchards selected were managed in the same way. In order to reduce the effect of the root stock and scion, nongrafted cultivars were used. None of these sites, except for site 2 , was treated with an insecticide during this study. The numbers of nymphs and eggs were recorded every six days from the 18 April to the end of September 2016. Overall each site was sampled 28 times. Four fully mature apical leaflets were cut using scissors $2 \mathrm{~m}$ above ground level from the four geographical sides of the trees,. After transfer to the laboratory, the number of nymphs, eggs and parasitized nymphs of common pistachio psyllid on the upper and lower parts of each leaflet were counted and summed for each the four sides. Concurrent with the sampling, the daily minimum and maximum temperatures were measured using a thermometer (TFA Co., Germany) placed inside a sheltered screen.

Samples of leaves were collected on 18 June 2016 from each of the trees sampled for CPP in order to quantify their contents of N, P, K, Fe, Zn, Cu and Mn. The sampling of the leaves was carried out following the protocol outlined by the Soil and Plant Analysis Laboratory of Agricultural and Natural Resources Research Centre of Yazd province by removing healthy mature leaves from the middle of infertile branches at a height of $2 \mathrm{~m}$. From each tree, 20 leaves were collected and placed in nylon bags on which the specifications of the specimen were written. They were then transferred to the Soil and Plant Analysis Laboratory of the Agricultural and Natural Resources Research Centre of Yazd province.

\section{Analyzing the elements in the leaves}

Once washed, the leaf samples were allowed to dry exposed in a sunny room. They were then ground to a powder and kept at $65^{\circ} \mathrm{C}$ for $24 \mathrm{~h}$ inside an incubator (Memmert Co., Germany). One gram of each sample was measured using a digital balance (And Co., Japan, precision .00001) and placed in a crucible in an electric oven (Therm Wise Co., South Korea) at $550^{\circ} \mathrm{C}$ for $6 \mathrm{~h}$, until it was completely burnt and converted into a white ash. Next, 10 $\mathrm{ml}$ of $\mathrm{HCl} 2 \mathrm{M}$ (Merck Pure Analyses, Germany) was added to each sample, which was put on an electric stove (T \& D Co., Iran) at a low temperature until it produced white steam, which indicates complete digestion. The resulting solution was purified by passing it through fine filter paper (Chm Co., F1002, Spain). The filtrate was used to quantify $\mathrm{P}, \mathrm{K}, \mathrm{Ca}, \mathrm{Mg}, \mathrm{Fe}, \mathrm{Cu}, \mathrm{Zn}$ and $\mathrm{Mn}$. 
After adding ammonium molybdate and ammonium vinyl acetate (both obtained from Merck Pure Analysis, Germany) to the samples, phosphorus content was measured using a spectrophotometer (Jenway Co. model 6105 UV/Vis, England) at a wavelength of $470 \mathrm{~nm}$. Potassium was quantified by adding Caesium chloride (Merck Pure Analysis, Germany) to the samples and using a flame photometer (Sherwood Co. Model 410, England). Iron, zinc, copper and manganese were quantified by means of atomic absorption (Perkin Elmer Co. Model 3110, America). Finally, an automatic Kjeldal apparatus (Gerhardt Co., Germany) was used to quantify nitrogen.

To determine the relationship between CPP population growth and leaf nutrients, we used multivariate regressions and STATISTICA software. Multivariate regressions were used to reduce the number of variables and determine the significance of the correlations between nutrients and CPP eggs and nymphs. The dependent variable, (CPP egg and nymph numbers), was extracted using the method of Southwood \& Jepson (SJ) (1962). Day-degrees rather than chronological time was used for drawing the SJ's graphs. The day-degree Celsius was calculated using the equation:

$\left(\mathrm{T}_{\max }-\mathrm{T}_{0}\right)^{2} / 2\left(\mathrm{~T}_{\max }-\mathrm{T}_{\min }\right)$

where $\mathrm{T}_{\max }=$ maximum temperature, $\mathrm{T}_{\min }=$ minimum temperature and $\mathrm{T}_{0}=$ lower thermal threshold for development ( 9.43 and $10.81^{\circ} \mathrm{C}$ for eggs and nymphs, respectively; Mehrnejad, 1998). Overall 74.07 and 169.5 DD, respectively, are required for the development of eggs and nymphs (Mehrnejad, 1998). Number of egg and nymph were measured by dividing the area under the SJ curves by DD and then subjecting the result to one-way ANOVA using SPSS. One-way ANOVA was used to test if egg and nymph numbers were similar in all orchards. The comparison of means were done using Tukey's HSD at 0.05 probability level.

\section{Life table experiment}

The effect of iron on outbreaks of CPP was determined in a field experiment. This experiment was carried out close to orchard site No. $2\left(32^{\circ} 16^{\prime} 9^{\prime \prime} \mathrm{N}, 53^{\circ} 58^{\prime} 54^{\prime \prime} \mathrm{E}\right)$ in Yazd-Meybod County in spring 2017. The experimental design involved 20 20-year old trees of the Ohadi cultivar, which is tolerant of CPP and rarely sprayed by farmers. This trial had two stages: in the first stage on 15 May, each tree was sprayed with a $50 \mathrm{~g}$ iron chelate $(6 \%)$ solution and 15 days later a bioassay was carried out. In the second stage, on 5 June, each tree previously treated with $\mathrm{Fe}$ and a control were sprayed with $150 \mathrm{~g}$ of a $21 \%$ solution of ammonium sulphate, and 15 days later they were also bio assayed.

The bioassay method was a modified version of the technique previously described for CPP (Mehrnejad, 1998, 2006). All laboratory studies were carried out under controlled conditions $\left(27.5 \pm 1{ }^{\circ} \mathrm{C}, 55 \pm 5 \% \mathrm{RH}\right.$ and $\left.16 \mathrm{~L}: 8 \mathrm{D}\right)$. Leaf disk cages were used for estimating the time required for development and fecundity of CPP. The cages were made of plastic Petri-dishes $(60 \mathrm{~mm}$ diameter) with a hole in the lids ( $20 \mathrm{~mm}$ diameter) covered by a piece of fine nylon mesh ( $2 \mathrm{~mm}$ mesh) for ventilation. A high humidity was maintained in each dish by means of a layer of agar (8 g/l), to which $100 \mathrm{ppm}$ of Captan 50\% WP (Ariashimi Co., Iran) was added to prevent the growth of mould. Young but fully developed leaves were cut from fertile pistachio trees treated with iron fertilizer and not treated as a control (stage 1), iron fertilizer + ammonium sulphate and ammonium sulphate fertilizer alone as a control (stage 2). The leaves were cut to the same size as the Petri-dish and the leaf, underside down, was placed on the thin layer of agar ( $5 \mathrm{ml}$ of agar). In order to maintain a moisture content of $55 \pm 5 \%, 20 \mathrm{~g}$ magnesium nitrate (Sepahan Rooyesh Co., Iran) was placed in each leaf cage. Eight leaf cages and two Petri dishes containing magnesium nitrate were placed in a transpar- ent plastic box $(22 \times 22 \times 5)$, which had a $20 \mathrm{~mm}$ hole in its lid, and then in an incubator (Memmert Co., Germany). The lighting inside the incubator was provided by a fluorescent lamp with a light intensity of $15 \mathrm{watts} / \mathrm{m}^{2}$. Twenty pairs of adult psyllids were collected from pistachio trees in the trial area and placed in five leaf disc cages under controlled conditions and allowed to lay eggs for $24 \mathrm{~h}$.

Leaf discs with psyllid eggs were inspected twice daily to determine their incubation period. Newly hatched nymphs were collected and individually placed on fresh leaf-discs using a fine hair brush. The nymphs were gently stimulated to remove their mouthparts from the leaf tissue. Trials to determine the time required by nymphs to complete their development began with 50 newly hatched nymphs. After three days, the nymphs were transferred to fresh leaf-discs. The stage of development of nymphs was checked daily and recorded until adults appeared. The sex of each adult was also recorded. During the experiment, dead and missing nymphs were also recorded, with missing nymphs and those trapped in the agar medium considered as dead. For egg incubation period and nymphal development, these experiments were repeated twice. In addition, the fecundity per day of a pair of newly emerged adults in leaf-disc cages was recorded. Each day, using a small aspirator, the adults were carefully transferred to a new leaf disc, and all the eggs laid on the old discs were counted and recorded. During the experiment, if a male died, a new male was added to the cage. In this experiment, the fecundity of each female psyllid was recorded for 12 days. The life table parameters, intrinsic rate of increase $\left(r_{m}\right)$, finite rate of increase $(\lambda)$, net reproductive rate $\left(\mathrm{R}_{0}\right)$ and mean generation time $(\mathrm{T})$ for cohorts of CPP fed on leaves treated with $\mathrm{Fe}, \mathrm{Fe}+$ nitrogen, nitrogen, and not treated were calculated using Carey's method (1993). Newton-Raphson's method was used to estimate $r_{m}$. Jackknife resampling technique (Noorini, 2012) was used to create pseudovalues of parameters for statistical comparisons. Student's t-test $(\alpha=0.05)$ was used for pairwise comparisons using SPSS.

\section{RESULTS}

\section{Regional survey}

The results revealed a significant difference in the abundance of eggs and nymphs at different locations $(\mathrm{F}=5.062$; $\mathrm{df}=3,20 ; \mathrm{P}$-value $=0.009$ for eggs; $\mathrm{F}=18.747 ; \mathrm{df}=3,20$; $\mathrm{P}$-value $<0.001$ for nymphs). The number of eggs at sites 1 and 2 placed them in one group and sites 3 and 4 in another, while the number of nymphs at sites 1,3 and 4 was similar and different from that recorded at site 2 .

At the beginning of the growing season (April and May), the abundance of eggs and nymphs of CPP was high at all four sites and then decreased. The abundance of eggs and nymphs was lower at sites 3 and 4 than at sites 1 and 2 . At the end of September, this pest again increased in abundance at all four sites (Figs 1 and 2).

The recommended contents of the different elements in pistachio leaves is: $\mathrm{N}=2.2-2.5 \%, \mathrm{P}=0.14-0.17 \%, \mathrm{~K}$ $=1.8-2.0 \%, \mathrm{Ca}=1.3-4.0 \%, \mathrm{Mg}=0.6-1.2 \%, \mathrm{Cu}=6-10$ ppm, $\mathrm{Zn}=10-15 \mathrm{ppm}, \mathrm{Mn}=30-80 \mathrm{ppm}, \mathrm{Fe}=100-120$ ppm and $B=150-250$ ppm (Malakouti et al., 2008), while that of the macroelements was normal at all four sites, that of certain microelements, especially iron, manganese and zinc, was well below the values cited above.

Multivariate regressions were used to remove unnecessary explanatory variables and to investigate the relation- 


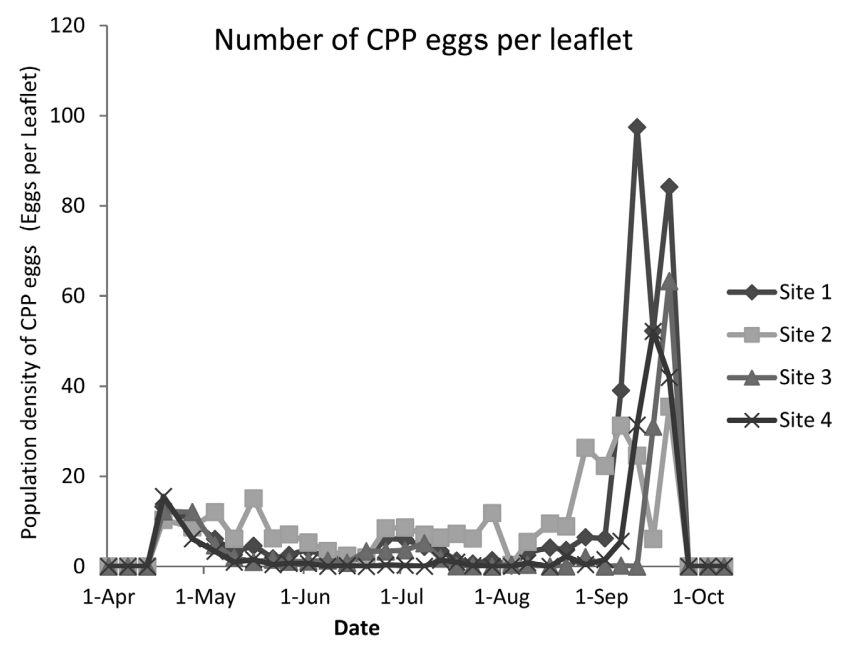

Fig. 1. Trends in the abundance of CPP eggs per leaflet recorded at four locations in Maybod county, Yazd Province, Iran in 2016.

ships between nutrients and the abundance of eggs and nymphs of CPP. The results indicated a significant relationship between the elements present in the leaves and the abundance of eggs $(\mathrm{F}=4.567, \mathrm{df}$ 's $=7,16, \mathrm{P}$-value $=0.0057$ adjusted $\left.\mathrm{R}^{2}=0.521\right)$, a negative relationship for iron and a positive one for copper (Table 1). The results also revealed a significant relationship between the elements present in the leaves and the abundance of nymphs of CPP (F $=3.369$, df's $=7,16$, P-value $=0.021$, adjusted $\left.\mathrm{R}^{2}=0.419\right)$, but only a negative relationship with iron (Table 1).

\section{Effect of the iron content of leaves on the population growth rate of CPP}

Before carrying out this experiment the leaves of trees treated with iron were analyzed, which revealed that iron was well absorbed (139 ppm), whereas in the control trees it was well below the normal value (90 ppm). Other elements except $\mathrm{Cu}$ were almost similar in the control and the trees treated with iron. This study had two stages. In the first stage, CPP developed significantly faster on the leaves from trees treated with Fe than those from the control. Almost all the life history parameters improved relative to those for the control. Except for GRR, DT and $\lambda(t=1.209$,

Table 1. Statistics of the relationships between the abundance of eggs and nymphs of CPP and the concentrations of various nutrients in the leaves of pistachio trees in orchards in the Maybodyazd province.

\begin{tabular}{lrrlllll}
\hline \multirow{2}{*}{ Model } & \multicolumn{3}{c}{ Egg } & & \multicolumn{3}{c}{ Nymph } \\
\cline { 2 - 4 } \cline { 6 - 8 } & St.Co $^{\text {a }}$ & Tol. $^{b}$ & P-value & & St.Co ${ }^{\mathrm{a}}$ & Tol. $^{\mathrm{b}}$ & P-value \\
\hline Regression & & & $0.006^{* *}$ & & & $0.021^{*}$ \\
Nitrogen & -0.145 & 0.717 & 0.407 & & -0.010 & 0.717 & 0.959 \\
Phosphorus & 0.184 & 0.924 & 0.239 & & 0.040 & 0.924 & 0.813 \\
Potassium & -0.155 & 0.623 & 0.408 & & -0.028 & 0.623 & 0.890 \\
Iron & -0.556 & 0.508 & $0.014^{*}$ & & -0.681 & 0.508 & $0.008^{* *}$ \\
Manganese & 0.160 & 0.523 & 0.422 & & 0.244 & 0.523 & 0.283 \\
Zinc & -0.456 & 0.366 & 0.069 & & -0.482 & 0.366 & 0.085 \\
Copper & 0.522 & 0.434 & $0.030^{*}$ & 0.334 & 0.434 & 0.185 \\
\hline
\end{tabular}

a - standardized coefficient; $b$ - collinearity diagnostics; ${ }^{*}-$ significant at $\alpha=0.05 ;{ }^{* *}-$ significant at $\alpha=0.01$.

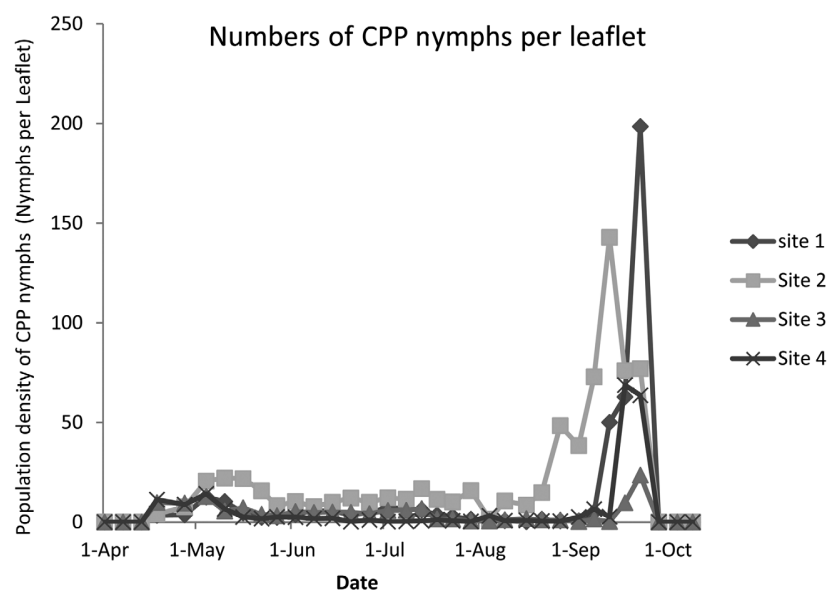

Fig. 2. Trends in the abundance of CPP nymphs per leaflet recorded at four locations in Maybod county, Yazd Province, Iran in 2016.

$\mathrm{df}=25, \mathrm{P}$-value $=0.238 ; \mathrm{t}=-1.704, \mathrm{df}=22, \mathrm{P}$-value $=$ $0.102 ; \mathrm{t}=-1.348, \mathrm{df}=38, \mathrm{P}$-value $=0.158$ respectively), mean values recorded for Fe-treated trees and the control differed significantly $(\mathrm{t}=2.717, \mathrm{df}=38, \mathrm{P}$-value $=0.01 ; \mathrm{t}$ $=2.141$, $\mathrm{df}=27, \mathrm{P}$-value $=0.042$ and $\mathrm{t}=-4.047, \mathrm{df}=38$, $\mathrm{P}$-value $<0.001$ for $\mathrm{r}_{\mathrm{m}}, \mathrm{R}_{0}$ and $\mathrm{T}$ respectively) (Table 2 ).

In the second stage, on 5 June, each of the trees previously treated with $\mathrm{Fe}$ and the control tree were treated with $150 \mathrm{~g}$ of $21 \%$ ammonium sulphate. There were no significant difference between the two groups except for GRR $(\mathrm{t}=2.681, \mathrm{df}=38, \mathrm{P}$-value $=0.01 ; \mathrm{t}=-0.278, \mathrm{df}=38$, $\mathrm{P}$-value $=0.782 ; \mathrm{t}=-0.170, \mathrm{df}=38, \mathrm{P}$-value $=0.866 ; \mathrm{t}=$ $-0.423, \mathrm{df}=38, \mathrm{P}$-value $=0.674 ; \mathrm{t}=-0.154, \mathrm{df}=38, \mathrm{P}-$

Table 2. Demographic parameters (Mean $\pm \mathrm{SE}$ ) of the psyllid, $A$. pistaciae, fed on leaves from pistachio trees treated with chelated iron and the control tree recorded under laboratory condition $\left(27.5 \pm 1^{\circ} \mathrm{C}, 50-60 \% \mathrm{RH}\right.$ and $16 \mathrm{~L}: 8 \mathrm{D}$ photoperiod).

\begin{tabular}{lcc}
\hline Life table parameters & Fe-treated & Control \\
\hline Gross reproductive rate $(\mathrm{GRR})^{\mathrm{ns}}$ & $71.3 \pm 12.60$ & $54.9 \pm 4.89$ \\
Net reproductive rate $\left(\mathrm{R}_{0}\right)^{*}$ & $35.6 \pm 10.21$ & $12.0 \pm 4.70$ \\
Intrinsic rate of increase $\left(\mathrm{r}_{\mathrm{m}}\right)^{* *}$ & $0.1563 \pm 0.0133$ & $0.0984 \pm 0.0167$ \\
Generation time $(\mathrm{T})^{\star *}$ & $23.1 \pm 0.48$ & $26.0 \pm 0.40$ \\
Finite rate of increase $(\lambda)^{\mathrm{ns}}$ & $1.069 \pm 0.015$ & $1.101 \pm 0.018$ \\
Doubling time $(\mathrm{DT})^{\mathrm{ns}}$ & $4.4 \pm 0.39$ & $6.8 \pm 1.40$ \\
\hline
\end{tabular}

ns - not-significant; ${ }^{*}-$ significant $(\alpha=0.05) ;{ }^{* *}-$ significant $(\alpha=$ $0.01)$.

Table 3. Demographic parameters (Mean $\pm \mathrm{SE}$ ) of the psyllid, $A$. pistaciae, fed on leaves from pistachio trees provided with one of two different nutrient treatments: iron and nitrogen or only nitrogen (control), recorded under laboratory condition $\left(27.5 \pm 1^{\circ} \mathrm{C}, 50-60 \%\right.$ R.H. and $16 \mathrm{~L}: 8 \mathrm{D}$ photoperiod).

\begin{tabular}{lcc}
\hline Life table parameters & $\mathrm{Fe}+\mathrm{N}$ treated & $\mathrm{N}$ treated control \\
\hline Gross reproductive rate $(\mathrm{GRR})^{\star \star}$ & $93.1 \pm 3.32$ & $70.1 \pm 7.93$ \\
Net reproductive rate $\left(\mathrm{R}_{0}\right)^{\mathrm{ns}}$ & $8.9 \pm 6.10$ & $12.5 \pm 5.90$ \\
Intrinsic rate of increase $\left(r_{m}\right)^{\mathrm{ns}}$ & $0.1056 \pm 0.0383$ & $0.1125 \pm 0.0226$ \\
Generation time $(\mathrm{T})^{\mathrm{ns}}$ & $23.9 \pm 0.27$ & $23.6 \pm 0.22$ \\
Finite rate of increase $(\lambda)^{\mathrm{ns}}$ & $1.110 \pm 0.041$ & $1.119 \pm 0.025$ \\
Doubling time $(\mathrm{DT})^{\mathrm{ns}}$ & $4.53 \pm 4.41$ & $5.83 \pm 1.51$ \\
\hline
\end{tabular}

ns - non-significant; ${ }^{*}$ - significant $(\alpha=0.05)$. 
value $=0.878 ; \mathrm{t}=0.905, \mathrm{df}=38, \mathrm{P}$-value $=0.371$ for $\mathrm{GRR}$, DT, $\lambda, \mathrm{R}_{0}, \mathrm{r}_{\mathrm{m}}$, and $\mathrm{T}$ respectively) (Table 3 ).

\section{DISCUSSION}

The results of this study provide strong evidence that variations in Fe significantly affect the population dynamics of the common pistachio psyllid both in the field and the laboratory. In general, trees with low levels of Fe tended to be infested with the highest populations of CPP. In the regional survey, the abundance of CPP was negatively correlated with variations in micronutrients in the leaves of the trees.

There is good evidence that the amount of amino acid and soluble nitrogen in plants are important in determining the growth and reproduction of sap sucking insects (Mengel \& Kirkby, 1982; Jansson \& Smilowitz, 1986; Cole, 1997; Altieri \& Nicolls, 2003; Chau et al., 2005; Golan et al., 2017).

Iron also plays a role in protein metabolism; there are two groups of well-known iron-rich proteins, heme proteins including prosthetic groups such as cytochromes and Fe-S proteins. During iron deficiency, the protein fraction declines with an increase in the level of soluble organic $\mathrm{N}$ compounds (Malakouti et al., 2008; Rout \& Sahoo, 2015). As a vital component of proteins and enzymes, iron plays a major role in biological processes, including photosynthesis, chlorophyll synthesis, respiration, nitrogen fixation and absorption. Iron deficiency disrupts the synthesis of enzymes and proteins from amino acids, and causes an accumulation of low molecular weight N-containing compounds in plant tissues (Kim \& Rees, 1992). Hence, the enzymatic reactions in plants are disrupted and they are not capable of producing protein from amino acids. This is similar to what happens when there is a deficiency of potassium in plant tissues (Myers \& Gratton, 2006).

There are a number of studies that indicate changes in the amount of $\mathrm{N}$ and $\mathrm{K}$ in plants can affect the population ecology of aphids and other sap-feeding insects (van Emden, 1966; Perrenoud, 1990; Waring \& Cobb, 1992; Cisneros \& Godfrey, 2001; Awmack \& Leather, 2002; Boyer et al., 2003; Gratton \& Denno, 2003; Golan et al., 2017).

Similarly, Fe deficiency in pistachio may alter the Navailability and make it a better resource for CPP.

A quantitative analysis of both free Nitrogen and individual amino acids in the phloem of Fe-deficient pistachio plants would indicate how this plant responds physiologically to Fe deficiency and provide further insight into the effect of Fe on the abundance of CPP recorded in this study.

CPP nymphs are abundant at the beginning of the growing season (April and May) and then the population rises sharply again at the end of September. There are two seasonal forms (winter and summer forms) and an intermediate-form of CPP, which differ in shape and fecundity. The winter-form and intermediate-form are highly fecund. The winter-form appears in early April in orchards and the intermediate-form when the photoperiod is less than $12 \mathrm{~h}$ and temperature is above $20^{\circ} \mathrm{C}$. Under natural conditions, the intermediate-form occurs in pistachio orchards during
October and November (Mehrnejad \& Copland, 2005). Probably, seasonal variations in soluble $\mathrm{N}$ compounds and amino acids are likely to account for the abundance of CPP at the beginning of the growing season (April and May) and end of September.

The best example of the importance of nitrogen and amino acids in determining the fecundity is the response of the sycamore aphid, Drepanosiphum platanoidis (Schrank), and wheat seedlings aphid, Rhopalosiphum padi (L.), to changes in the quality of phloem sap. At the beginning of the growing season, the amount of amino acid in phloem is high and individual aphids are large and highly fecund. As the leaves mature, phloem amino acids decrease and aphid reproduction stops. When the leaves become old, fecundity rises in response to an increase in content of amino acids in the phloem sap (Wellings et al., 1985; Weibull, 1987).

The results of the leaf disc experiments showed that CPP performed better and natural populations of CPP increase more rapidly on Fe treated pistachio trees. This response was principally caused by a marked increase in the fecundity of CPP on leaves from trees treated with Fe compared with the control. This result differs from that of the regional survey. Iron deficiency strongly affected the growth and development of the plant, whereas an excess of iron in cells is toxic. The optimal concentration of iron for the growth of pistachio trees is 100-120 ppm. Higher iron uptake by plants reduces protein synthesis in leaves (Rout \& Sahoo, 2015). In our experiment, the concentration of iron in treated pistachio was $139 \mathrm{ppm}$ and $90 \mathrm{ppm}$ in the control. This may have increased the amount of amino acid in the leaves and improved the growth and fecundity of CPP.

In aphids, $\mathrm{Fe}$ seems to be essential for reproduction, while $\mathrm{Zn}$, Co and $\mathrm{Ca}$ enhance growth and reduce mortality, with $\mathrm{Ca}$ being critical for adult development. Traces of $\mathrm{Ca}, \mathrm{Cu}, \mathrm{Fe}, \mathrm{Mn}$, and $\mathrm{Zn}$ are essential for the maintenance of intracellular symbiosis (Panizzi \& Parra, 2012). Thus, it is likely that an excess of iron in pistachio leaves provided favourable conditions for the growth and development of CPP.

Effect of fertilizer applications differ among herbivore insects. According to a number of reviews, fertilizers do not affect the fecundity of aphids, while other studies report increases in fecundity. One reason for this difference may be the lack of a linear relationship between the application of fertilizer and aphid growth and development. Another reason may be that mineral ratios affect herbivore insect performance (Busch \& Phelan, 1999; Jansson \& Ekbom, 2002; Chau et al., 2005). The relationship between fecundity and development of CPP and iron content of the leaves of pistachio may not be linear. Alternatively, it is the ratio of iron to other minerals that is important.

In N-treated plants the addition of Fe had no effect on the abundance of CPP. Net replacement rate and intrinsic rate of increase were similar to those recorded on the control trees not treated with fertilizer. On plants receiving $\mathrm{Fe}+\mathrm{N}$ fertilizers GRR was significantly higher and the $\mathrm{R}_{0}$-value was lower than on N-treated plants. This may indicate a high pre-reproductive and reproductive mortality. This is 
opposite of that recorded on Fe-treated plants. It seems that nitrogen decreased generation time by shortening the reproductive period. As a result, there was a small nonsignificant increase in intrinsic rate of increase. These results are in accordance with the results of studies on other sap sucking insects, especially aphids. Aphids and other phloem feeding insects are especially sensitive to changes in plant macronutrients such as N (Pfeiffer \& Burts, 1983; Waring \& Cobb, 1992; Awmack \& Leather, 2002; Jansson \& Ekborn, 2002; Davies et al., 2004; Chau et al., 2005). While life table parameters improved after applying $\mathrm{N}$ fertilizer to the control trees, on the trees previously treated with iron before applying $\mathrm{N}$ fertilizer $\mathrm{R}_{0}$ and $\mathrm{r}_{\mathrm{m}}$ of CPP decreased in the leaf disc experiment, with $\mathrm{R}_{0}$ decreasing from 35.63 to $8.9, \mathrm{r}_{\mathrm{m}}$ from 0.1563 to 0.1056 , while $\mathrm{T}$ increased from 23.1 to 23.9 , DT from 4.49 to $4.53, \lambda$ from 1.069 to 1.101 and GRR from 71.3 to 93.1 .

The ratio of iron to nitrogen might also be important. Therefore, when there is a deficiency of iron, the application of $\mathrm{N}$-fertilizers enhances the performance of the common pistachio psyllid.

ACKNOWLEDGMENTS. We appreciate the help of A. Shahed and S.Y Mousavi in locating suitable orchards in Yazd-Meybod County and allowing us to sample CPP on their farms. We also acknowledge the assistance and cooperation of the Meteorological Office of Meybod and Plant Protection Administration of Yazd province.

\section{REFERENCES}

Altieri M.A. \& Nicholls C. 2003: Soil fertility management and insect pests: harmonizing soil and plant health in agroecosystems. - Soil Tillage Res. 72: 203-221.

Arab-Hormozabadi A. 2005: Study of Biological and Behavioural Aspects of Ladybird, Adalia bipunctata a Predatory Insect of the Common Pistachio Psylla. MSc Thesis, University of Shahid Chamran, Ahvaz, 88 pp. [in Persian].

AUCLAIR J.L. 1965: Feeding and nutrition of the pea aphid, Acrythosiphon pisum (Homoptera: Aphidae) on chemically defined diets of various $\mathrm{pH}$ and nutrient levels. - Ann. Entomol. Soc. Am. 58: 855-875.

AwMack C.S. \& Leather S.R. 2002: Host plant quality and fecundity in herbivorous insects. - Annu. Rev. Entomol. 47: 817-844.

Boyer A.G., Swearingen R.E., Blaha M.A., Fortson C.T., Gremillion S.K., Osborn K.A. \& Moran M.D. 2003: Seasonal variation in top-down and bottom-up processes in a grassland arthropod community. - Oecologia 136: 309-316.

Busch J.W. \& Phelan P.L. 1999: Mixture models of soybean growth and herbivore performance in response to nitrogensulphur-phosphorus nutrient interactions. - Ecol. Entomol. 24: 132-135.

CAREY J.R. 1993: Applied Demography for Biologists with Special Emphasis on Insects. Oxford University Press, New York, 206 pp.

Chau A., Heinz K.M. \& Davies F.T. 2005: Influences of fertilization on population abundance, distribution, and control of Frankliniella occidentalis on Chrysanthemum. - Entomol. Exp. Appl. 117: 27-39.

Cisneros J.J. \& Godfrey L.D. 2001: Midseason pest status of the cotton aphid (Homoptera: Aphididae) in California cotton: Is nitrogen a key factor? - Environ. Entomol. 30: 501-510.
Cole R.A. 1997: The relative importance of glucosinolates and amino acids to the development of two aphid pests Brevicoryne brassicae and Myzus persicae on wild and cultivated Brassica species. - Entomol. Exp. Appl. 85: 121-133.

DALE D. 1988: Plant-mediated effects of soil mineral stresses on insects. In Heinrichs E.A. (ed.): Plant Stress-Insect Interactions. John Wiley \& Sons, New York, pp. 35-110.

Davies F.T., He C., Chau A., Heinz K.M. \& Cartmill A.D. 2004: Fertility effects susceptibility of Chrysanthemum to cotton aphids: Influence of plant growth photosynthesis, ethylene evolution and herbivore abundance. - J. Am. Soc. Hortic. Sci. 129: 344-353.

Ebrahimi S.J., Shahidi-Zandi K. \& Mehrnejad M.R. 1999: Population fluctuation of a parasitoid and three hyperparasitoids of the pistachio psylla. - Pajouhesh-va-Sazandegi 40: 62-64 [in Persian].

Golan K., Sempruch C., Gorska-Drabik E., Czerniewicz P., Lagowska B., Kot I., Kmiec K., Magierowicz K. \& LeszcZYNSKI B. 2017: Accumulation of amino acids and phenolic compounds in biochemical plant responses to feeding of two different herbivorous arthropod pests. - Arthr.-Plant Interac. 11: $675-682$.

Gratton C. \& Denno R. 2003: Seasonal shift from bottom-up to top-down impact in phytophagous insect populations. - Oecologia 134: 487-495.

Hassani M.R., Mehrnejad M.R. \& Ostovan H. 2009: Some biological and predation characteristics of Oenopia conglobata contaminata (Col.: Coccinellidae) on the common pistachio psylla in laboratory conditions. - Iran. J. Forest Protec. Res. 6: 110-117 [in Persian].

Jalali M.A. 2001: Study of Food Consumption in Predatory Beetles (Col.: Coccinellidae) of the Common Pistachio Psyllid, Agonoscena pistaciae in Rafsanjan, and Compiling a Life Table in the Controlled Condition. MSc Thesis, University of Shiraz, 110 pp. [in Persian].

JAnsson J. \& Еквом B. 2002: The effect of different plant nutrient regimes on the aphid Macrosiphum euphorbiae growing on petunia. - Entomol. Exp. Appl. 104: 109-116.

JANSSON R.K. \& SMILOWITZ Z. 1986: Influence of nitrogen on population parameters of potato insects: Abundance, population growth, and within-plant distribution of the green peach aphid, Myzus persicae. - Environ. Entomol. 15: 49-55.

Kazemi F. \& Mehrnejad M.R. 2011: Seasonal occurrence and biological parameters of common green lacewing predators of the common pistachio psylla, Agonoscena pistaciae (Hemiptera: Psylloidea). — Eur. J. Entomol. 108: 63-70.

KIM J. \& ReEs D.C. 1992: Structural models for the metal centers in the nitrogenous molybdenum-iron protein. - Science $\mathbf{2 5 7}$ : 1677-1682.

Malakouti M.J., Keshavarz P. \& Karimian N. 2008: A Comprehensive Approach towards Identification of Nutrients Deficiencies and Optimal Fertilization for Sustainable Agriculture. Tarbiat-Modarres University Press, 755 pp. [in Persian].

MenRnejad M.R. 1998: Evaluation of the Parasitoid Psyllaephagus pistaciae (Hymenoptera: Encyrtidae) as a Biocontrol Agent of the Common Pistachio Psylla Agonoscena pistaciae (Hemiptera: Psylloidea). Ph.D. Thesis, University of London, $271 \mathrm{pp}$.

Menrnejad M.R. 2003: Pistachio Psylla and other Major Psyllids of Iran. Agricultural Research and Education Organization, Teheran, 114 pp. [in Persian].

MenRnejad M.R. 2006: Three pistachio species evaluated for resistance to the common pistachio psylla, Agonoscena pistaciae. In Kamata N., Liebhold A.M., Quiring D.T. \& Clancy K.M. (eds): Proccedings of the IUFRO Kanazawa 2003 Inter- 
national Symposium "Forest Insect Population Dynamics and Host Influences". Kanazawa University, Kakuma, Ishikawa, pp. 58-62.

Menrnejad M.R. 2010: Potential biological control agents of the common pistachio psylla Agonoscena pistaciae, a review. Entomofauna 31: 317-340.

Menrnejad M.R. \& Copland M.J. W. 2005: The seasonal forms and reproductive potential of the common pistachio psylla, Agonoscena pistaciae (Hemiptera: Psylloidea). — J. Appl. Entomol. 129: 342-346.

Mehrnejad M.R. \& Emami S.Y. 2005: Parasitoids associated with the common pistachio psylla, Agonoscena pistaciae in Iran. Biol. Contr. 32: 385-390.

Mehrnejad M.R. \& Ueckermann E. 2001: Mites (Arthropoda: Acari) associated with pistachio trees (Anacardiaceae) in Iran (I). - Syst. Appl. Acarol. Spec. Publ. 6: 1-12.

Mehrnejad M.R. \& Ueckermann E. 2002: Phytophagous and predatory mites of the pistachio trees in Iran. - Acta Hortic. 591: 545-547.

Mehrnejad M.R., Vahabzadeh N. \& Hodgson C.J. 2015: Relative suitability of the common pistachio psyllid, Agonoscena pistaciae (Hemiptera: Aphalaridae), as prey for the two-spotted ladybird, Adalia bipunctata (Coleoptera: Coccinellidae). Biol. Contr. 80: 128-132.

Mengel K. \& Kirkby E.A. 1982: Principles of Plant Nutrition. $3 r d$ ed. International Potash Institute, Worblaufen, Bern, 655 pp.

Myers S.W. \& Gratton C. 2006: Influence of potassium fertility on soybean aphid, Aphis glycines Matsumura (Hemiptera: Aphididae), population dynamics at a field and regional scale. — Environ. Entomol. 35: 219-227.

NoorinI M. 2012: Jackknife variance estimation in dual frame surveys. - Iran. J. Offic. Statist. Stud. 23: 103-127 [in Persian].
PANIzZI A.R. \& PARRA J.R.P. 2012: Insect Bioecology and Nutrition for Integrated Pest Management. CRC Press by Taylor \& Francis, London, 705 pp.

Perrenoud S. 1990: Potassium and Plant Health. 2nd ed. International Potash Institute, Basel, $364 \mathrm{pp}$.

Pfeiffer D.G. \& BurTs E.C. 1983: Effect of tree fertilization on numbers and development of pear psylla (Homoptera: Psyllidae) and on fruit damage. - Environ. Entomol. 12: 895-901.

Pourali Z., Kheradmand K. \& Mehrnejad M.R. 2012: Effects of temperature on biological parameters of Anthocoris minki pistaciae (Hemiptera: Anthocoridae). - Zool. Ecol. 22: 240245.

Rout G.R. \& SAHOo S. 2015: Role of iron in pant growth ad metabolism. - Rev. Agric. Sci. 3: 1-24.

Southwood T.R.E \& JePSON W.F. 1962: Studies on the populations of Oscinella frit L. (Diptera: Chloropidae) in the oat crop. - J. Anim. Ecol. 31: 481-495.

VAN EMdEN H.F. 1966: Studies on the relations of insect and host plant. III. A comparison of the reproduction of Brevicoryne brassicae L. and Myzus persicae Sulz. (Hemiptera: Aphididae) on brussels sprout plants supplied with different rates of nitrogen and potassium. - Entomol. Exp. Appl. 9: 444-460.

WARING G.L. \& CoBB N.S. 1992: The impact of plant stress on herbivore population dynamics. In Bernays E. (ed.): InsectPlant Interactions. Vol. 4. CRC Press, Boca Raton, pp. 167226.

Weibull J. 1987: Seasonal changes in the free amino acids of oat and barley phloem sap in relation to plant growth stage and growth of Rhopalosiphum padi. - Ann. Appl. Biol. 111: 729-738.

Wellings P.W., Chambers R.J., Dixon A.F.G. \& Aikmant D.P. 1985: Sycamore aphid number and population density I. Some pattern. - J. Anim. Ecol. 54: 411-424.

Received February 9, 2019; revised and accepted April 23, 2019 Published online June 20, 2019 